\title{
Coexistence of cor triatriatum and rheumatic mitral stenosis in an adult patient
}

\author{
Erişkin bir hastada mitral darlık ve kor triatriatum’un beraberliği
}

\author{
Necla Özer, Hakan Aksoy, Onur Sinan Deveci, Erol Tülümen, Enver Atalar, Kenan Övünç, Serdar Aksöyek \\ Department of Cardiology, Faculty of Medicine, Hacettepe University, Ankara, Turkey
}

\section{Introduction}

Cor triatriatum sinistrum is a rare congenital cardiac anomaly especially in adulthood. Improved diagnostic techniques lead the cardiologists to the right diagnosis of this anomaly. We present in this paper a case of cor triatriatum with mitral stenosis.

\section{Case Report}

A 50-year-old woman was referred to Hacettepe University Cardiology Department for echocardiographic examination. She had a history of acute rheumatic fever 30 years ago. Two-dimensional transthoracic echocardiogram demonstrated diastolic doming of anterior mitral leaflet and a membrane subdividing the left atrium into two chambers (Fig. 1, Video $1 \mathrm{a}$ and $1 \mathrm{~b}$. See corresponding video/movie images at www.anakarder. com). Transvalvular mean gradient was $3 \mathrm{mmHg}$ and mitral valve area was $2.4 \mathrm{~cm}^{2}$ with area trace method consistent with mild obstruction. A transesophageal echocardiography was performed and a membrane from ridge between left atrial appendage and left pulmonary vein to interatrial septum in the left atrium was revealed (Fig. 2, Video 2. See corresponding video/movie images at www.anakarder.com).

\section{Discussion}

Cor triatriatum sinister is a rare condition in which the clinical features on presentation can mimic those of mitral stenosis due to the obstructive properties of the membrane. The most common presenting symptoms in adults are dyspnea, hemoptysis and orthopnea (5). Classically, patients present during the neonatal period or early infancy and $75 \%$ of untreated patients die in infancy or rarely survive beyond childhood without early diagnosis and surgical intervention, although in some instances cases remain undetected until the patient is an adult (6). The presentation age and severity of symptoms differs according to the size of the membrane fenestrations. Patients with larger membrane fenestrations generally present later and these patients mostly have less transmembrane flow obstruction (7). Pulmonary capillary wedge pressure and mean pressure gradients are significantly higher in younger adults. The incidence of atrial fibrillation and mitral regurgitation is found to rise with advancing age (7).

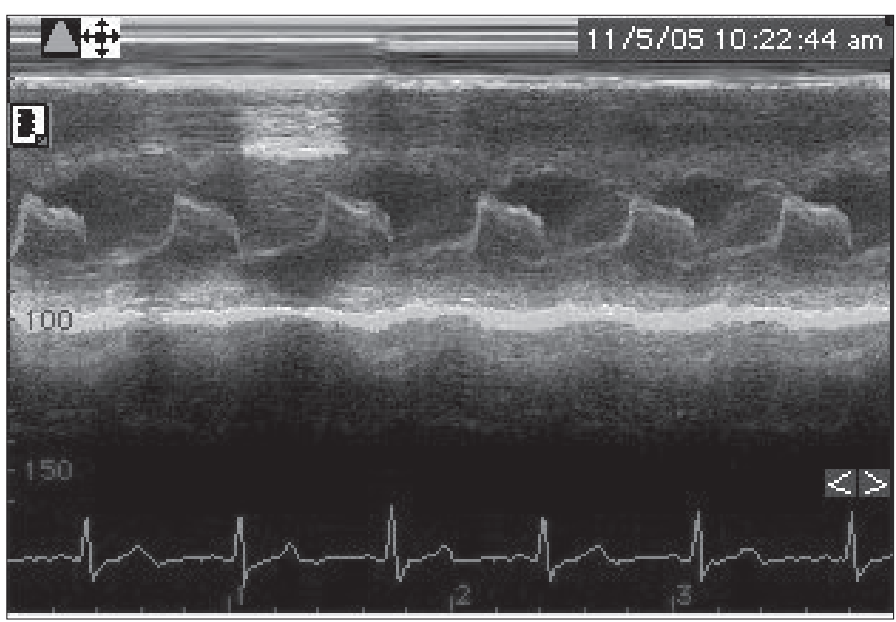

Figure 1. M-mode echocardiographic view of the mitral valve with a decreased EF slope demonstrating mitral stenosis

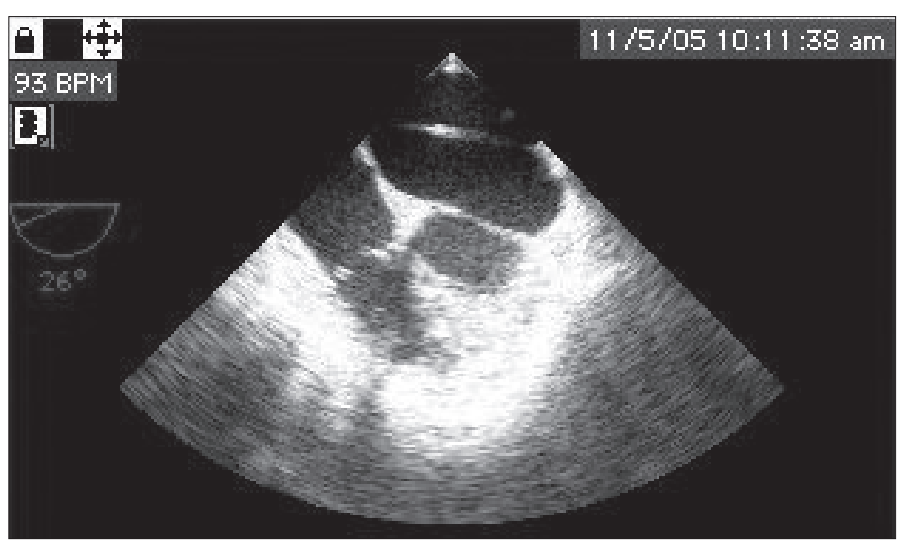

Figure 2. Transesophageal view of a membrane in left atrium

The other congenital cardiac anomalies like atrial septal defect, patent foramen ovale and pulmonary venous return anomalies may also accompany the cor triatriatum.

Address for Correspondence/Yazışma Adresi: Necla Özer, MD, Hacettepe University Faculty of Medicine, Department of Cardiology Sıhhiye, Ankara, Turkey Phone: +90 3123051780 Fax: +90 3123114058 E-mail: neclaozer@hotmail.com

(C) Telif Hakkı 2010 AVES Yayıncılık Ltd. Şti. - Makale metnine www.anakarder.com web sayfasından ulaşılabilir.

(C) Copyright 2010 by AVES Yayıncilk Ltd. - Available on-line at www.anakarder.com doi:10.5152/akd.2010.048 
It is likely that diagnostic accuracy has increased due to technological developments and widespread availability of transthoracic and transesophageal echocardiography. This may lead to increase in the reported cases of cor triatriatum in the literature.

When the cor triatriatum is the only abnormality the clinical findings are very similar to mitral stenosis, because both conditions cause pulmonary hypertension and subsequently elevated pulmonary capillary pressures, pulmonary arterial hypertension and right heart chamber enlargements. The possibility of a left atrial membrane should be actively considered when signs and symptoms of mitral stenosis are present. The presence of membrane and absence of anterior leaflet doming excludes the possibility of rheumatic mitral stenosis. However, rarely two conditions may present together like in our patient. In the presence of both conditions, the correct method for calculation of mitral valve mean and peak gradients and measurement of mitral valve area with pressure half time method is conflicting.

\section{Conclusion}

Cor triatriatum sinister remains an uncommon form of congenital heart disease, although it is being diagnosed with increasing frequency in adults due to improvements in diagnostic imaging. In this case, cor triatriatum was incidentally revealed in a patient with mitral stenosis.

\section{References}

1. Church WS. Congenital malformation of the heart: abnormal septum in the left auricle. Trans Pathol Soc Lond 1868; 19: 188-90.

2. Van Son JAM, Danielson GK, Schaff HV, Puga FJ, Seward JB, Hagler DJ, et al. Cor triatriatum: diagnosis, operative approach and late results. Mayo Clin Proc 1993; 68: 854-9.

3. Rodefeld MD, Brown JW, Heimansohn DA, King H, Girod DA, Hurwitz RA, et al. Cor triatriatum: clinical presentation and surgical results in 12 patients. Ann Thorac Surg 1990; 50: 562-8.

4. Tsutsumi K, Ookura M. Asymptomatic cor triatriatum incidentally revealed in an elderly patient with mitral stenosis. Jpn J Thorac Cardiovasc Surg 2003; 51: 452-5.

5. Mc Guire LB, Nolan TB, Reeve R, Dammann Jr JF. Cor triatriatum as a problem of adult heart disease. Circulation 1965; 31: 263-72.

6. Feld H, Shani J, Rudansky HW, Rudyak E, Greengart A. Initial presentation of cor triatriatum in a 55 year-old woman. Am Heart J 1992; 124: 788-91.

7. Slight RD, Nzewi OC, Buell R, Mankad PS. Cor triatriatum sinister presenting in the adult as mitral stenosis: an Analysis of factors, which may be relevant in late presentation. Heart Lung Circ 2005; 14: 8-12.

\title{
Adult bi-ventricular noncompaction cardiomyopathy
}

\author{
Yetişkin biventriküler noncompaction kardiyomiyopati
}

\author{
Giovanni Minardi, Carla Manzara, Giovanni Pulignano, Giuseppe Paolo Pino, Herribert Pavaci' ${ }^{\text {, }}$ Martina Sordi ${ }^{1}$ \\ Department of Cardiology, Azienda Ospedaliera S. Camillo-Forlanini, Rome \\ ${ }^{1}$ Department of Cardiology, Sapienza University, Rome, Italy
}

\section{Introduction}

Noncompaction cardiomyopathy (NCM) is an idiopathic disorder characterized by an altered structure of the myocardial wall as a result of intrauterine arrest of compaction of the myocardial fibers in the absence of any coexisting congenital lesion (1).

The diagnosis is based on $2 \mathrm{D}$ echocardiography (2), or magnetic resonance imaging (MRI) or computed tomography (CT) scans (3).

In this case report, the typical echocardiographic images, angiographic, $\mathrm{MRI}$ and histological results of a case with noncompaction cardiomyopathy and both ventricles involvement (BVNCM).

\section{Case Report}

A 29-year-old male was referred to our institution because of palpitations. The electrocardiogram showed an atrial flutter and left bundle branch block (LBBB).
Transthoracic echocardiography (TTE) and transesophageal echocardiography (TEE) showed features of BVNCM (Fig. 1, 2): dilated and globally hypokinetic left ventricle (LV) (ejection fraction-38\%), prominent trabecularization of the apex and the mid-lateral wall, deep intertrabecular recesses with flow coming out from ventricular cavity; the end-systolic thickness ratio between noncompacted and compacted myocardium was 2.5; the apex of the right ventricle was hypokinetic and heavily trabeculated, with evident flow in intertrabecular recesses. During these examinations, the patient was in atrial flutter with a well-controlled ventricular rate response. The left atrium (LA) was mildly dilated, with spontaneous echo-contrast of $2^{\circ}-3^{\circ}$ degrees. A mild-moderate mitral regurgitation and tricuspid regurgitation were present and systolic pulmonary arterial pressure (sPAP) was $48 \mathrm{mmHg}$.

The patient underwent endo-esophageal biphasic DC shock and sinus rhythm was restored.

Angiographic study showed enlarged and globally hypokinetic LV with trabeculated apex and elevated right-sided pressure. Endomyocardial biopsy showed mild myocardial hypertrophy and thickened capillary

Address for Correspondence/Yazışma Adresi: Giovanni Minardi, MD, Azienda Ospedaliera S.Camillo-Forlanini Cardiology, Via Sebino 11-00199 Rome, Italy Phone/Fax: +39 (0) 85302557 E-mail: giovanni.minardi@libero.it

(C) Telif Hakkı 2010 AVES Yayıncılık Ltd. Sti. - Makale metnine www.anakarder.com web sayfasından ulaşılabilir.

(C) Copyright 2010 by AVES Yayıncillk Ltd. - Available on-line at www.anakarder.com doi:10.5152/akd.2010.049 